\title{
STUDA BIBLICA
}

Since 1971, Studia Biblica et Theologica has provided opportunity for students interested in the scholarly pursuit of biblical and theological topics to publish their work. $S B T$ seeks not only to provide a stimulus to students by giving them a goal to aim for in their research, but aspires to contribute significantly to the basic fund of biblical and theological knowledge, thereby serving both the theological community and the Church.

$S B T$ invites students in seminaries and graduate schools of religion to submit quality essays in biblical studies, theology and related disciplines for consideration for publication. Essays must be written in English and conform to the "Instructions for Contributors" published in the Journal of Biblical Literature (95 [1976] 331-46). Manuscripts over 50pp. in length will not be considered. All manuscripts should be submitted in duplicate and become the property of $S B T$. Please direct articles to:

\author{
Prof. James E. Bradley \\ General Editor, SBT \\ Fuller Theological Seminary \\ 135 N. Oakland Avenue \\ Pasadena, CA 91101 USA
}

Studia Biblica et Theologica is published twice yearly, in April and October, with each issue comprising approximately 72pp. $S B T$ is typeset, perfect bound and trimmed to $5 \frac{1}{2} \times 81 / 2$ inches. $S B T$ is indexed in Elenchus Bibliographicus Biblicus, Internationale Zeitschriftenschau für Bibelwissenschaft und Grenzgebiete and Old Testament Abstracts. Subscriptions to SBT are $\$ 5.00$ per year ( $\$ 6.00$ outside the USA). Multiple-year subscriptions for up to three years are accepted. All subscriptions must be prepaid. Please send order and payment (in US dollars) to: Gary A. Tuttle, Managing Editor, SBT, at the address noted above. 


\section{THE CHURCH BEFORE THE COVENANTS The Church of Scotland I $596-$ I 638 Walter Roland Foster}

A fresh assessment of the national Church of Scotland in the early seventeenth century, a crucial period in its history when the reformed Kirk was not only completely united but, equally important, thoroughly presbyterian and fully episcopal. Considerable progress was made in the spread of presbyteries, the establishment of reformed parishes, the growth of schools, and the financial reorganization of the Church. A pragmatic solution as much as a doctrinaire one, the Scottish Church was a unique Reformation experiment.

Rather than rely solely upon the polemical histories written at the time, Professor Foster has drawn on primary sources - presbytery minutes, synod records, journals, letters and wills - and thus achieves a closer understanding of the ordinary operation of the Church, which is revealed as both effective and harmonious, and not beset by intense rivalry or factions.

Apart from its historical importance, Professor Foster's study has clear implications for re-union plans which seek to embrace both the reformed and episcopal traditions.

Demy 8vo 224 pp.

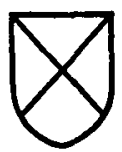




\section{保 \\ THE HANDSEL PRESS}

The Handsel Press was set up in 1975 in association with the Scottish Academic Press. It aims to publish theological books falling generally into two categories: those speaking from the "centre" of Christian faith, directed at ministers, theological students and interested laymen, and books which will explore key frontiers with Christian faith and ethics in such fields as education, psychology, medicine and other sciences.

Here are two titles from the Press recently published

\section{Theology as Narration}

\section{G. A. F. KNIGHT}

This work is primarily a verse-by-verse commentary upon the book of Exodus that pays first attention to theology and exegesis, although on occasions important issues such as the relationship between science and magic, the hardening of the heart, the twilight of the gods, etc., are dealt with in some detail.

$216 \times 138 \mathrm{~mm} .236$ pp. 905312015 £5.00

\section{Space, Time and Resurrection}

\section{T. F. TORRANCE}

This work deals with the Resurrection in relation to space and time, with special relation to time. It attempts to set out the biblical approach to the Resurrection, in terms of the intrinsic significance of the resurrected one; and shows that the Resurrection is entirely consistent with who Jesus was and what $\mathrm{He}$ did, and is continuous with His whole reality.

All this is elucidated in the context of modern scientific thought and questioning, in such a way as to show that far from being frightened into a miserable compromise of the New Testament message of the Resurrection of Jesus Christ in body, it actually allows us to take its full measure. The implications of this are drawn out for eschatology and the renewal of the creation.

$216 \times 138 \mathrm{~mm}$. 224 pp. $905312007 £ 5.00$ 


\section{UNIVERSITY OF ST. ANDREWS}

\section{CHAIR OF DIVINITY}

Applications are invited for the CHAIR OF DIVINITY which is now vacant. Salary within professorial range; FSSU/USS. Applications (preferably in typescript) with the names of three referees should be lodged by 16 th October 1978 with the Establishments Officer, The University, College Gate, St. Andrews, Fife, from whom further particulars may be obtained. 


\section{NOTES FOR GONTRIBUTORS}

Contributions and editorial correspondence should be sent to one of the editors: Rev. Dr A. I. C. Heron, New College, Mound Place, Edinburgh EHI 2LX; Rev. Dr J. Houston, University of Glasgow, 3 Southpark Terrace, Glasgow g 12 8QQ or to Scottish Academic Press Ltd., 33 Montgomery Street, Edinburgh EH7 5Jx.

Submission of an article is taken to imply that it has not previously been published in English, or is not being considered by another journal for publication in English. In the interests of authors, copyright is normally assigned to the Scottish Academic Press. The average length of articles is 5000 words. Although longer articles are accepted, those in excess of 10,000 words cannot be considered.

Contributions (articles and reviews) should be clearly typed in double spacing, and on one side of the paper only. The rule about double spacing applies also to footnotes, which should be used sparingly. Cross-references within the article offered should not be included.

Notes for the editors and instructions for the printer should be attached on separate sheets. Contributors should keep one copy of the typescript for use in correcting proofs.

Contributors from the United States may use U.S. spellings. Greek and Hebrew words need not be transliterated. Capitalisation should be kept to a minimum; and in particular should not be used in pronouns referring to the Deity.

First proofs of articles and reviews may be read and corrected by contributors, and should normally be returned to the organising editor within ten days of receipt. Correction should be confined to errors of the printer. More extensive correction can be made only with the concurrence of an editor. No proofs of reviews will be sent.

Contributors of articles and article reviews (but not of reviews) receive 10 free offprints. Extra copies may be bought according to an agreed scale of charges, provided that these are ordered at the time of returning corrected proofs.

\section{PERMISSIONS}

For permission to reproduce material from Scottish Journal of Theology please apply to the Scottish Academic Press, 33 Montgomery Street, Edinburgh EH7 $5 \mathrm{Jx}$. 


\section{SCOTTISH JOURNAL OF THEOLOGY \\ VOLUME 31 No. 4}

\section{GONTENTS}

The Kerygma and the Cuckoo's Nest,

by Peter Slater

Indian Christian Theology-The Humanity of Christ and the New Humanity,

by Frank Whaling

The New Jerusalem in Matthew 5.I4,

by K. M. Campbell

Article Review: Tillich as a Philosopher of Religion, by J. Heywood Thomas

\section{REVIEWS}

TORRANGE: Space, Time and Resurrection

HICK: Death and Eternal Life

GOBB and GRIFFIN : Process

Theology: an Introductory

Exposition

SPARN: Weiderkehr der Metaphysik

MaY: Paulus: a Personal Portrait of Paul Tillich

GAGER: Kingdom and Community

VAN LeEuWEn: Critique of Earth

Bibliographical Essays in

Medieval Jewish Studies. The

Study of Judaism-Vol. 2
KLINE: The Sayings of Jesus in the Pseudo-Clementine Homilies

BARTCHY: First-Century Slavery and $\mathrm{I}$ Corinthians 7.21

CALloud: Structural Analysis of Narrative

FOSTER: The Church before the Covenants: The Church of Scotland, I 596-1638

Martin: John Keble: Priest, Professor and Poet

CRIChton: Christian Celebration:

The Prayer of the Church

BARRow: Moral Philosophy for Education 